\title{
Negative Regulation of Cell-Cell Adhesion
}

National Cancer Institute

\section{Source}

National Cancer Institute. Negative Regulation of Cell-Cell Adhesion. NCI Thesaurus.

Code C40709.

Any cellular process that reduces the frequency, rate or extent of adhesion between cells. 